\title{
Ni-based catalysts for steam reforming of tar model derived from biomass gasification
}

\author{
Ru Shien Tan ${ }^{1}$, Afizah Alir ${ }^{1}$, Saiful Azam Mohamad ${ }^{1}$, Khairuddin Md Isa ${ }^{2}$, and Tuan Amran \\ Tuan Abdullah, ${ }^{1 *}$ \\ ${ }^{1}$ Department of Chemical Engineering, School of Chemical and Energy Engineering, Faculty of \\ Engineering, Universiti Teknologi Malaysia, 81310 Johor Bahru, Johor, Malaysia. \\ ${ }^{2}$ School of Environmental Engineering, Universiti Malaysia Perlis, Kompleks Pusat Pengajian Jejawi \\ 3, 02600 Arau, Perlis, Malaysia.
}

\begin{abstract}
Tar formation during biomass gasification is a major barrier to utilise the produced syngas, which clogs processing equipment. In the present study, steam reforming of gasification-derived tar (phenol, toluene, naphthalene, and pyrene) was catalysed by $\mathrm{Ni} /$ dolomite, $\mathrm{Ni} /$ dolomite $/ \mathrm{Al}_{2} \mathrm{O}_{3}, \quad \mathrm{Ni} /$ dolomite $/ \mathrm{La}_{2} \mathrm{O}_{3}, \quad \mathrm{Ni} /$ dolomite $/ \mathrm{CeO}_{2}, \quad$ and $\mathrm{Ni} /$ dolomite $/ \mathrm{ZrO}_{2}$ for hydrogen production. The steam reforming experiment was conducted in a fixed bed reactor at $700{ }^{\circ} \mathrm{C}$ and the steamto-carbon molar ratio of 1 under atmospheric pressure. After the catalytic test, the spent catalysts were characterised by thermogravimetric analysis and variable-pressure scanning electron microscope. The aim of this study is to investigate the catalytic activity of Ni-based catalysts in terms of tar conversion and their deactivation characteristic. The current results revealed that all the catalysts showed almost full conversion of $\operatorname{tar}(98.8 \%-$ 99.9\%) and considerably low amount of coke deposited in the form of amorphous and filamentous carbon (15.9-178.5 mg g $\left.\mathrm{gat}^{-1}\right)$. Among the catalysts studied, $\mathrm{Ni} /$ dolomite $/ \mathrm{La}_{2} \mathrm{O}_{3}$ gave the highest catalytic activity for steam reforming of gasified biomass tar and lowest coke formation.
\end{abstract}

\section{Introduction}

In recent decades, biomass gasification is the most environmentally friendly and economical technology to substitute conventional fossil fuel-based gasification for the production of electricity, fuels, and chemicals [1,2]. Biomass is a sustainable and renewable organic source, including agricultural waste, municipal solid waste, and animal residue. Compared to non-renewable resources such as coal and natural gas, the utilisation of biomass as feedstock for gasification is more environmentally benign and clean. This is due to the carbon neutral feature of biomass [3].

Biomass gasification converts organic carbonaceous substances into syngas rich in hydrogen and carbon monoxide along with a small amount of carbon dioxide, methane, and impurities (such as tar, ash, sulphur, and nitrogen-containing compounds). The tar content in syngas varies from 0.5 to $100 \mathrm{~g} \mathrm{~m}^{3}$, depending on the type and design of gasifier.

*Corresponding author: tuanamran@utm.my 
However, most syngas applications require a tar content lower than $0.05 \mathrm{~g} \mathrm{~m}^{3}$ [4]. Hence, the presence of unacceptable tar level in syngas is the main challenge of biomass gasification. The formation of condensable tar in syngas implies that less biomass is converted into syngas and also contributes to syngas end-user problems such as blockages in downstream filters, fuel lines, engine nozzles, and even turbines [5]. Therefore, removal of tar and subsequent conversion tar to valuable gas are the important steps that need to be considered in biomass gasification process.

Among the existing approaches, catalytic steam reforming is a well-developed and attractive conversion technology that converts tar into valuable $\mathrm{H}_{2}$-rich gas. Presently, nonnoble transition metals ( $\mathrm{Ni}$ and $\mathrm{Co}$ ) and noble metals ( $\mathrm{Pt}, \mathrm{Ru}, \mathrm{Pd}$, and $\mathrm{Rh}$ ) are adopted as the active metals in steam reforming catalysts [6]. From an economic point of view, Nibased catalyst is more practical due to its low price and high activity for bond rupture [7]. Unfortunately, as it is well known, Ni-based catalyst usually suffers from deactivation by coke formation on the active sites at high temperature [8].

Furthermore, tar comprises of various condensable hydrocarbons that vary from monocyclic to polycyclic aromatic hydrocarbons and also primary oxygenated to heavier deoxygenated hydrocarbons [9]. The typical constituents of biomass tar are $46 \%$ of 1-ring aromatic hydrocarbons (mainly toluene), $28 \%$ of 2-ring aromatic hydrocarbons (mainly naphthalene), $7 \%$ of phenolic compound, $7 \%$ of 3- and 4-ring aromatic hydrocarbons, and $12 \%$ of others [10]. Heavy polycyclic aromatic hydrocarbons that are contained in tar are much more difficult to be reformed [11], whereas oxygenated hydrocarbons promote coke deposition on the catalyst [7]. In order to balance the trade-off between catalytic performance and economics in tar conversion, a study on steam reforming of gasified biomass tar over a newly developed Ni-based catalyst is necessary.

Recently, dolomite has been used as the catalyst support [12] or $\mathrm{CO}_{2}$ sorbent [13] in steam reforming field. Due to its alkalinity and $\mathrm{CO}_{2}$ capture ability, dolomite plays an important role in coke suppression [12] and promotes water-gas shift reaction, which results in $\mathrm{H}_{2}$-rich fuel gas production [13]. However, the low reactivity towards heavy tar conversion [14] and quick erosion feature in calcined state [15] make it less favourable to be used as a support. Thus, in this research, a combination of dolomite promoter and oxide supports $\left(\mathrm{Al}_{2} \mathrm{O}_{3}, \mathrm{La}_{2} \mathrm{O}_{3}, \mathrm{CeO}_{2}\right.$, and $\left.\mathrm{ZrO}_{2}\right)$ was suggested to improve catalytic performance in terms of catalytic activity and coke suppression.

\section{Experimental methods}

\subsection{Catalyst preparation}

All the catalysts were synthesised using co-impregnation method and their compositions are listed in Table 1. Nickel nitrate hexahydrate was used as the precursor of active metal. The catalysts were formulated with various oxide supports including dolomite $\left(\mathrm{CaMg}\left(\mathrm{CO}_{3}\right)_{2}\right), \gamma-$ $\mathrm{Al}_{2} \mathrm{O}_{3}, \mathrm{La}_{2} \mathrm{O}_{3}, \mathrm{CeO}_{2}$, and $\mathrm{ZrO}_{2}$. The catalysts were designated as NiD, NiDAl, NiDLa, NiDCe, and NiDZr. The resulting pastes were then dried at $110^{\circ} \mathrm{C}$ overnight and calcined in air at $800{ }^{\circ} \mathrm{C}$ for $3 \mathrm{~h}$. Lastly, the catalysts were pelletised, ground, and sieved into particle sizes of 500-800 $\mu \mathrm{m}$. 
Table 1. Weight percentage compositions of catalysts.

\begin{tabular}{|l|c|c|c|c|c|c|}
\hline \multicolumn{1}{|c|}{ Catalyst } & $\begin{array}{c}\mathrm{Ni} \\
\text { (wt. \%) }\end{array}$ & $\begin{array}{c}\text { Dolomite } \\
\text { (wt. \%) }\end{array}$ & $\begin{array}{c}\mathrm{Al}_{2} \mathrm{O}_{3} \\
\text { (wt. \%) }\end{array}$ & $\begin{array}{c}\mathrm{La}_{2} \mathrm{O}_{3} \\
\text { (wt. \%) }\end{array}$ & $\begin{array}{c}\mathrm{CeO}_{2} \\
\text { (wt. \%) }\end{array}$ & $\begin{array}{c}\mathrm{ZrO}_{2} \\
\text { (wt. \%) }\end{array}$ \\
\hline $\mathrm{Ni} /$ dolomite & 10 & 90 & - & - & - & - \\
\hline $\mathrm{Ni} /$ dolomite $/ \mathrm{Al}_{2} \mathrm{O}_{3}$ & 10 & 10 & 80 & - & - & - \\
\hline $\mathrm{Ni} /$ dolomite $/ \mathrm{La}_{2} \mathrm{O}_{3}$ & 10 & 10 & - & 80 & - & - \\
\hline $\mathrm{Ni} /$ dolomite $/ \mathrm{CeO}_{2}$ & 10 & 10 & - & - & 80 & - \\
\hline $\mathrm{Ni} /$ dolomite $/ \mathrm{ZrO}_{2}$ & 10 & 10 & - & - & - & 80 \\
\hline
\end{tabular}

\subsection{Catalytic activity test}

Catalytic steam reforming performance was investigated in a fixed bed reactor operated at $700{ }^{\circ} \mathrm{C}$ and $\mathrm{S} / \mathrm{C}$ molar ratio of 1 under atmospheric pressure using a mixed compound derived from gasified biomass tar. The tar was made up of $15 \mathrm{wt} \%$ of phenol, $50 \mathrm{wt} . \%$ of toluene, $30 \mathrm{wt}$. $\%$ of naphthalene, and 5 wt. $\%$ of pyrene. The catalyst and silicon carbide (1:2.5 weight ratio) were mixed and loaded into the reactor with $0.0127 \mathrm{~m}$ inner diameter. Prior to the experiment, the catalyst was reduced in 10 vol. $\% \mathrm{H}_{2} / \mathrm{N}_{2}$ stream at $900{ }^{\circ} \mathrm{C}$ for $\mathrm{Al}_{2} \mathrm{O}_{3}$-supported catalyst and $800{ }^{\circ} \mathrm{C}$ for the others for $1 \mathrm{~h}$. Water was vapourised by a preheater and carried to the reactor by $50 \mathrm{ml} \mathrm{min}^{-1}$ of $\mathrm{N}_{2}$ flow. Meanwhile, the tar model was directly fed into the reactor using a syringe pump at $0.02 \mathrm{ml} \mathrm{min}{ }^{-1}$.

The liquid product was recovered in the condenser and analysed using a gas chromatograph (HP 5890 Series II) equipped with flame ionisation detector and Agilent DB1 capillary column (polysiloxane, $30 \mathrm{ml} \times 0.53 \mathrm{~mm}$ ID, $1.5 \mu \mathrm{m}$ film thickness). The total tar conversion was expressed as Equation 1.

$$
\text { Tar compound conversion }(\%)=\frac{[\text { Tar }]_{\text {in }}-[\text { Tar }]_{\text {out }}}{[\text { Tar }]_{\text {in }}} \times 100
$$

\subsection{Coke analysis}

The amount of coke deposited on spent catalysts was determined by thermogravimetric analysis (TGA) using a thermogravimetric analyser (Shimadzu's TGA-50). The catalysts were heated to $800{ }^{\circ} \mathrm{C}$ with a heating rate of $10^{\circ} \mathrm{C} \mathrm{min}$ under air environment. Variablepressure scanning electron microscope (VP-SEM, JEOL JSM-IY300LV) was used to investigate the nature of coke deposited on spent catalysts at an accelerating voltage of 10 $\mathrm{kV}$.

\section{Results and discussion}

Figure 1 presents tar conversion for different catalysts during steam reforming of gasified biomass tar model. The catalytic performance in tar conversion was ranked in the order of $\mathrm{NiDLa}>\mathrm{NiDCe}>\mathrm{NiDAl}>\mathrm{NiDZr}>\mathrm{NiD}$. As shown in Figure 1, all the catalysts showed high activity in tar conversion (98.8\%-99.9\%) for $5 \mathrm{~h}$ of reaction time. NiDLa catalyst demonstrated a slightly higher tar conversion among the catalysts studied. This may be attributed by the high activity of NiDLa for tar destruction (C-C and C-H bonds cleavage).

On the other hand, NiD catalyst showed the lowest tar conversion. In this case, dolomite $\left(\mathrm{CaMg}\left(\mathrm{CO}_{3}\right)_{2}\right)$ was used in a calcined state $(\mathrm{CaO} / \mathrm{MgO})$ for steam reforming of gasified 
biomass tar model. During the steam reforming process, $\mathrm{CaO}$ in calcined dolomite captured the produced $\mathrm{CO}_{2}$ via carbonation $\left(\mathrm{CaO}+\mathrm{CO}_{2} \rightarrow \mathrm{CaCO}_{3}\right)$. Therefore, the lowest tar conversion of $\mathrm{NiD}$ catalyst may be explained by the carbonation of $\mathrm{CaO}$, which leads to loss of metallic properties of dolomite support. This statement is in accordance with the finding of Shuai et al. [16] that the catalytic activity of $\mathrm{CaO}$ in steam reforming decreased dramatically in the carbonated form.

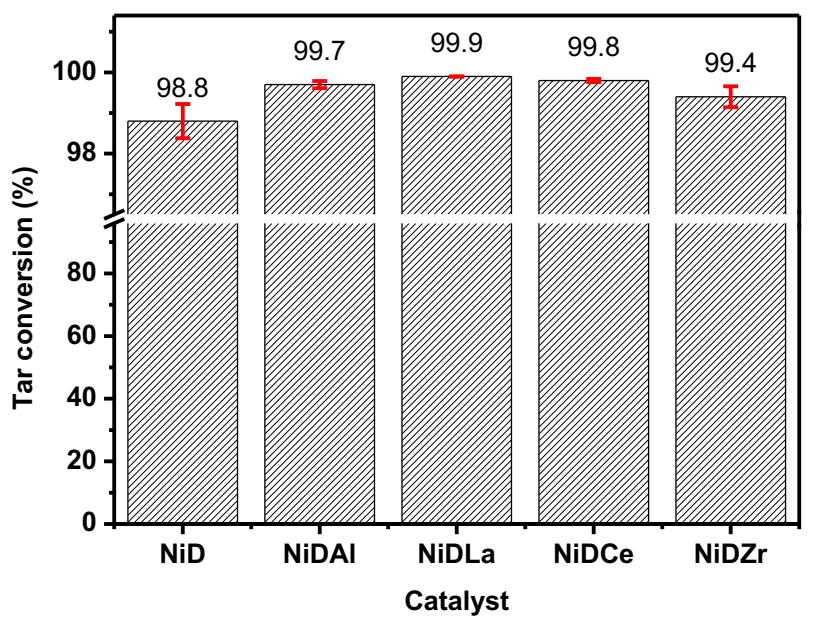

Fig. 1. Catalytic steam reforming of gasified biomass tar using various Ni-based catalysts at $700{ }^{\circ} \mathrm{C}$ with $\mathrm{S} / \mathrm{C}=1$ and GHSV $=20453 \mathrm{ml} \mathrm{g} \cdot \mathrm{h}^{-1}$.

During steam reforming, unreacted carbon adsorbed on the catalyst surface may obstruct the active sites of catalyst and deactivate the catalyst, eventually hindering steam reforming reaction. In order to investigate the coking resistance of each catalyst studied, the properties of coke deposition on each catalyst after $5 \mathrm{~h}$ of catalytic activity test were characterised by TG analysis. The amount of coke deposition is proportional to the reduction of weight during TG analysis (Figure 2), considering it only associates to coke oxidation. Coke deposited over the catalyst surface can be divided into amorphous and filamentous carbons. In the literature, amorphous carbon (oxidised around $400{ }^{\circ} \mathrm{C}$ ) causes catalyst deactivation, whereas filamentous carbon (oxidised at $550-750{ }^{\circ} \mathrm{C}$ ) does not significantly contribute to deactivation but leads to reactor blockage and pressure depression [17]. Additional weight gain was also observed in Figure 2, which might be explained by the oxidation of metallic Ni particles. 


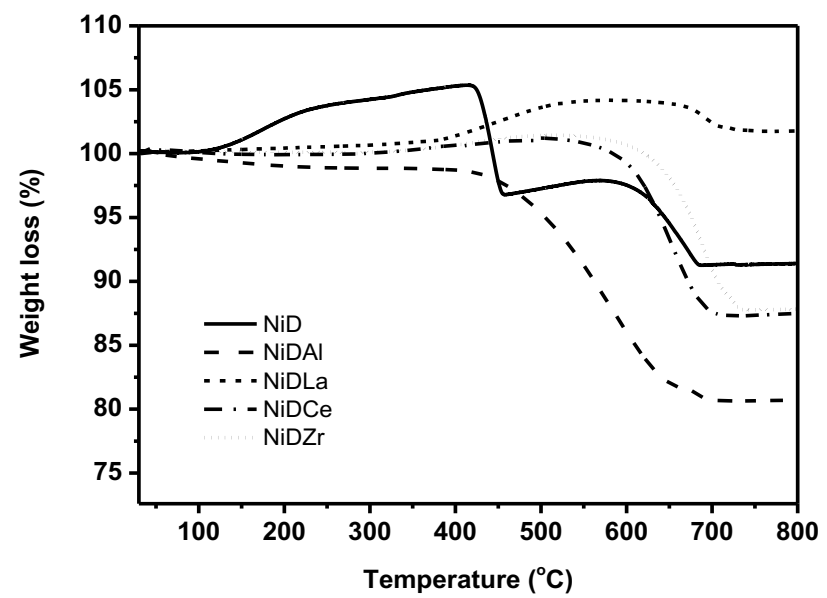

Fig. 2. Thermogravimetric curves of spent catalysts after catalytic activity test.

As shown in Figure 3, spent NiD and NiDAl catalysts were deposited by amorphous and filamentous carbons after the catalytic activity test. Meanwhile, only filamentous carbon was deposited on spent NiDLa, NiDCe, and NiDZr catalysts after $5 \mathrm{~h}$ of reaction time. The results of TGA were confirmed by the VP-SEM analysis, as can be seen in Figure 4. Only filamentous carbon was clearly visible on spent NiDLa catalyst but both amorphous and filamentous carbons were observed on spent NiDAl catalyst.

In the present study, spent NiDLa catalyst had the smaller amount of coke formation, which was around one-seventh of the other catalysts. This is due to the basicity of activated steam to facilitate coke gasification $\left(\mathrm{C}+\mathrm{HO}_{2} \rightarrow \mathrm{CO}+\mathrm{H}_{2}\right)$ on Ni surface [18]. Besides, $\mathrm{LaO}_{3}$ also removed the deposited coke by adsorbing $\mathrm{CO}_{2}$ to form lanthanum oxycarbonate $\left(\mathrm{La}_{2} \mathrm{O}_{2} \mathrm{CO}_{3}\right)$ and subsequently reacted with deposited coke to produce $\mathrm{La}_{2} \mathrm{O}_{3}$ and $\mathrm{CO}$ [19]. Although NiD catalyst also possessed high alkalinity, the coke formation of $\mathrm{NiD}$ determined by the weight loss from TG analysis was remarkable among the catalysts studied. This is because the large amount of weight loss during TG analysis might be ascribed to not only coke oxidation but also the calcination of $\mathrm{CaCO}_{3}\left(\mathrm{CaCO}_{3} \rightarrow \mathrm{CaO}+\right.$ $\mathrm{CO}_{2}$ ). The calcination is related to the thermal decomposition of $\mathrm{CaCO}_{3}$ formed during steam reforming to become $\mathrm{CaO}$ again.

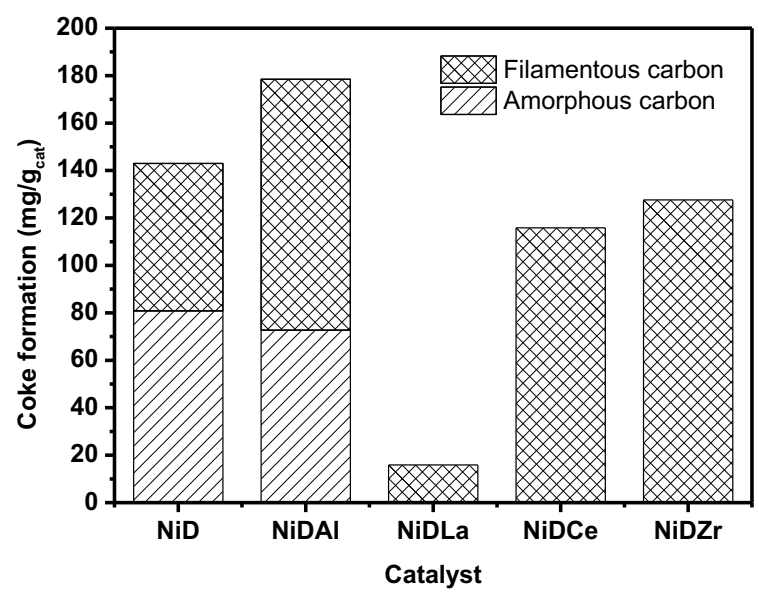

Fig. 3. Coke deposition on spent catalysts after catalytic activity test. 

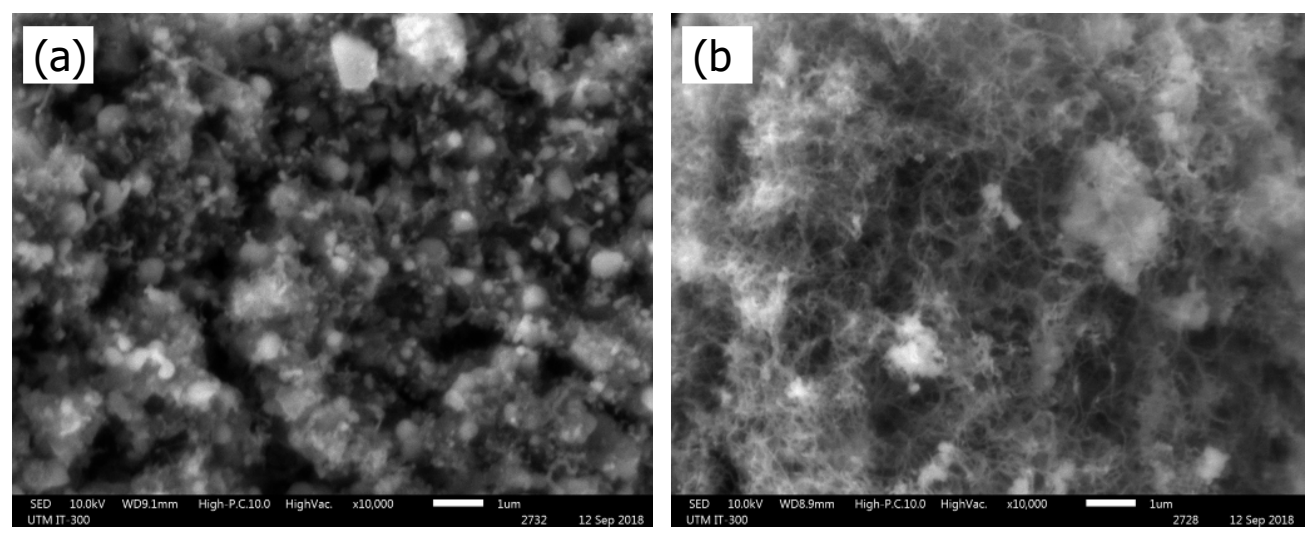

Fig. 4. VP-SEM images of (a) NiDAl and (b) NiDLa spent catalysts with $1000 \times$ magnification.

\section{Conclusion}

Steam reforming of gasified biomass tar model was carried out over NiD, NiDAl, NiDLa, NiDCe, and NiDZr catalysts. NiDLa catalyst is more preferable for steam reforming of gasified biomass tar by showing the highest tar conversion. Besides, NiDLa catalyst experienced the least amount of coke formation and only filamentous type was observed on spent NiDLa catalyst. Thus, the capability of NiDLa to retain the catalytic activity during steam reforming is affirmed. In conclusion, NiDLa catalyst is a promising catalyst for steam reforming of gasified biomass tar owing to its excellent catalytic performance and outstanding anti-coking ability.

The authors acknowledge the financial support from Universiti Teknologi Malaysia through Research University Grant (GUP Tier 1, No. 20H52).

\section{References}

1. V. Chiodo, F. Urbani, G. Zafarana, M. Prestipino, A. Galvagno, S. Maisano, Int. J. Hydrogen Energy 42 (46), 28048-28055 (2017)

2. A. Molino, S. Chianese, D. Musmarra, J. Energy Chem. 25 (1), 10-25 (2016)

3. G. Guan, M. Kaewpanha, X. Hao, A. Abudula, Renew. Sustain. Energy Rev. 58, 450461 (2016)

4. N.K. Pattar, S.S. Gowreesh, Int. J. Eng. Res. Tecnol. 6 (8), 62-70 (2017)

5. M. Artetxe, M.A. Nahil, M. Olazar, P.T. Williams, Fuel 184, 629-636 (2016)

6. V. Palma, C. Ruocco, E. Meloni, A. Ricca, Catal. 7 (8), 226-238 (2017)

7. M. Artetxe, J. Alvarez, M.A. Nahil, M. Olazar, P.T. Williams, Energy Convers. Manage. 136, 119-126 (2017)

8. S. Vivanpatarakij, D. Rulerk, S. Assabumrungrat, Chem. Eng. Trans. 37, 205-210 (2014)

9. C. Li, K. Suzuki, Renew. Sustain. Energy Rev. 13 (3), 594-604 (2009)

10. Y. Shen, K. Yoshikawa, Renew. Sustain. Energy Rev. 21, 371-392 (2013) 
11. F. M. Josuinkas, C.P. Quitete, N.F. Ribeiro, M.M. Souza, Fuel Process. Technol. 121, 76-82 (2014)

12. T. Wang, J. Chang, C. Wu, Y. Fu, Y. Chen, Biomass Bioenergy. 28 (5), 508-514 (2005)

13. M. Sisinni, A. D. Carlo, E. Bocci, A. Micangeli, V. Naso, Energies 6 (7), 3167-3181 (2013)

14. D. Dayton, National Renewable Energy Laboratory, NREL/TP-510-32815 (2002)

15. T. Nordgreen, Doctoral Thesis, KTH Royal Institute of Technology, (2011)

16. C. Shuai, S. Hu, L. He, J. Xiang, S. Su, L. Sun, L. Jiang, Y. Wang, Q. Chen, C. Liu, H. Chi, Int. J. Hydrogen Energy 40 (39), 13314-13322 (2015)

17. S.Y. Park, G. Oh, K. Kim, M.W. Seo, H.W. Ra, T.Y. Mun, J.G. Lee, S.J. Yoon, Renew. Energy 105, 76-83 (2017)

18. F. Zhang, M. Wang, L. Zhu, S. Wang, J. Zhou, Z. Luo, Int. J. Hydrogen Energy 42 (6), 3667-3675 (2017)

19. J. H. Song, S. Yoo, J. Yoo, S. Park, M. Y. Gim, T. H. Kim, I. K. Song, Mol. Catal. 434, 123-133 (2017) 